\title{
GEO ENERGY RESEARCH AND DEVELOPMENT:
}

TECHNOLOGY TRANSFER

SAND8 2-0211
SAND- $-82-0211$

DE82 009386

R. K. Traeger

Geo Energy Technology Department II

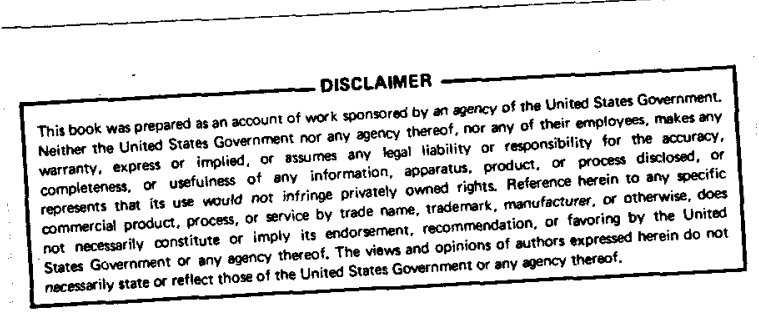

Abstract

Sandia Geo Energy Programs related to geothermal, coal, oil and gas, and synfuel resources have provided a useful mechanism for transferring laboratory technologies to private industry. Significant transfer of hardware, computer programs, diagnostics and instrumentation, advanced materials, and in situ process understanding has occurred through US/DOE supported programs in the past five years. The text briefly reviews the technology transfer procedures and summarizes 32 items that have been transferred and another 20 technologies that are now being considered for possible transfer to industry. A major factor in successful transfer has been personal interactions between Sandia engineers and the technical staff from private industry during all aspects of the technology development. 


\section{DISCLAIMER}

This report was prepared as an account of work sponsored by an agency of the United States Government. Neither the United States Government nor any agency Thereof, nor any of their employees, makes any warranty, express or implied, or assumes any legal liability or responsibility for the accuracy, completeness, or usefulness of any information, apparatus, product, or process disclosed, or represents that its use would not infringe privately owned rights. Reference herein to any specific commercial product, process, or service by trade name, trademark, manufacturer, or otherwise does not necessarily constitute or imply its endorsement, recommendation, or favoring by the United States Government or any agency thereof. The views and opinions of authors expressed herein do not necessarily state or reflect those of the United States Government or any agency thereof. 


\section{DISCLAIMER}

Portions of this document may be illegible in electronic image products. Images are produced from the best available original document. 
TABLE OF CONTENTS

$\underline{\text { Page }}$

Geo Energy Technology: Transfer from Sandia to Industry (Introduction).

Geo Energy Research and Development:

Technology Transfer . . . . . . . . . . . . . 3

Geo Energy Technology Transfer. . . . . . . . . . . 9

Technology Transferred . . . . . . . . . . . 9

New Concepts

Drilling, Completions and Mining . . . 9

Diagnostics. . . . . . . . . . . . 10

Processes. . . . . . . . . . . . 11

Risk Removal

Drilling, Completions and Mining . . . . 11

Diagnostics. . . . . . . . . . . . 14

Processes. . . . . . . . . . . . . 14

\section{Information}

Drilling, Completions and Mining . . . 17

Diagnostics... . . . . . . . . . . 17

Processes. . . . . . . . . . . . 17

Technology with Potential for Transfer . . . . . 17

New Concepts

Drilling, Completions and Mining . . . 17

Diagnostics. . . . . . . . . . . 18

Processes. . . . . . . . . . . 19

Risk Removal

Drilling, completions and Mining .... 19

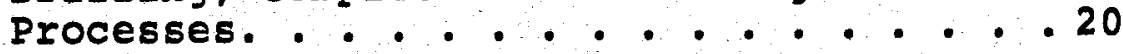

summary . . . . . . . . . . . . . . . . 21

References. ....................... 23

Appendices

A. Advisory Panels. . . . . . . . . . . . 25

B. Major Publications . . . . . . . . . . 29

C. Exhibits.................. 35 



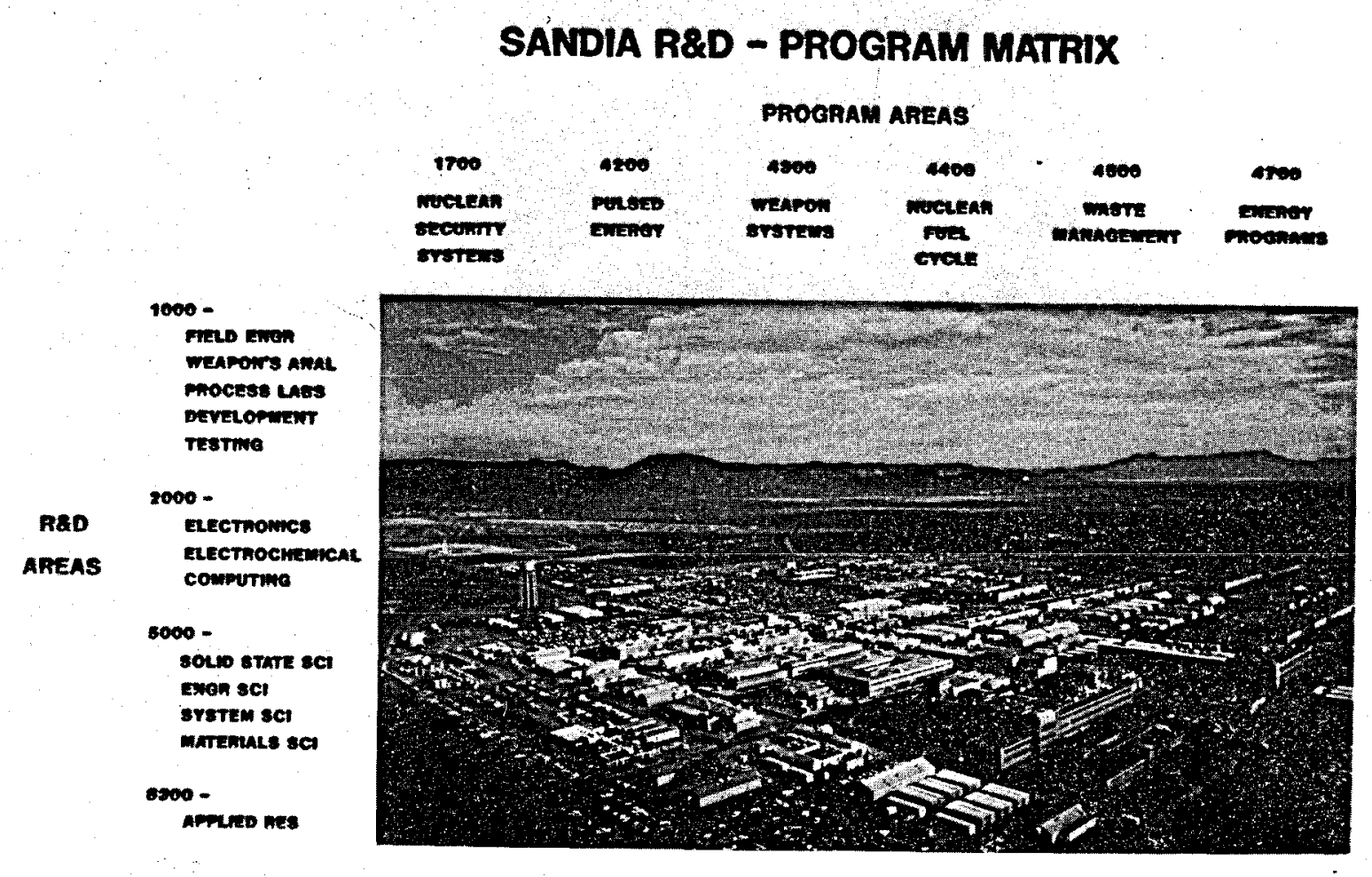

Matrix system provides an effective mechanism for utilizing advanced weapons technologies to meet energy and other non-weapon needs. 
GEO ENERGY TECHNOLOGY :

TRANSFER FROM SANDIA TO INDUSTRY

Recognition that mechanical switching devices could never meet the increasing demands of communication networks, Bell Telephone Labs initiated a research program resulting in the now ubiquitous transistor. This successful development with the ensuing transfer of multiple technologies to many industries is a recognized achievement of this century and details are well documented [e.g., References 1,2]. This concept of research directed to solve a problem with a requirement of transferring results to a manufacturing facility has been passed down from Bell Laboratories to Sandia for developing the sophisticated, high reliability components needed for nuclear weapon systems. Since all the weapon components are produced by captive private industry, all advanced technology has to be transferred effectively from the government laboratory to industrial process 1 ines on defined schedules.

When the energy shortage had serious national security implications and the national laboratories were asked to assist development of solutions, Sandia made a conscious decision to apply its technology base to resolve problems then existing in the fossil and geothermal energy producing communities rather than to develop new energy producing concepts. This decision required intimate interactions with industry personnel from the research labs to field operations. The decision also implied, in many cases, an understanding of the economics, definition of a development schedule and a product that would be adopted by private industry.

This report is a summary of those results from the Geo Energy (geothermal, fossil and synfuels) Programs at Sandia. The following briefly reviews technology transfer concepts, how they were evolved by Sandia, and then summarizes the technology that has been or is being transferred. Composition of the industrial advisory panels and some relevant references are included in the appendix for general information. This report will hopefully demonstrate that government laboratories and private industry can work effectively to solve national problems and the results can catalyze further industry-laboratory interactions. 
GEO ENERGY RESEARCH AND DEVELOPMENT:

TECHNOLOGY TRANSFER

Large government investments in R\&D result in many developments that have potential application in U.S. industry. The mechanism of transferring this technology has been the subject of books [3-5], conferences $[6,7]$ and many papers. NASA [8] has implemented a major technology transfer program including state, university and industry applications centers, a computer software and management center, a distribution of NASA Tech Briefs and applications teams. Nevertheless, the amount of spinoff technology from all government $R \& D$ has been disappointing considering the total federal investments [9]. A number of reasons for limited spinoff are given in Table 1.

As mentioned earlier, Sandia chose to use their capabilities to directly transfer technology to energy producing industries. A number of mechanisms have been suggested for transferring technology; some are listed in Table 2 . However, with all the rhetoric, modeling and analyses, one fact keeps being repeated:

"The key to successful technology transfer lies not in procedures, but people." [12]

"...feedback, direct personal links...direct contacts" [13]

"The real problem is that we ignore the human involvement." [14]

Technology transfer is "movement of people... agents versus agencies." [15]

"In fact, it appears that the early establishment of a strong innovator -- manufacturer linkage -strong enough so that the manufacturer becomes the co-inventor - is one of the keys to successful transfer of federal laboratory technology."

Successful transfer requires "a champion." [14]

To assure strong communication Iinks, extensive industrial interaction is designed into 211 programs as outlined in Table 3. The "Stages of Development" are standard for an R\&D program with the exception of a continuing system and economic analyses through the development activities to:

Identify critical areas requiring R\&D plus those that have the most potential for influencing costs 
Table 1. Impediments to technology transfer from national laboratories

Lag Time:

An approximate six-year lag time [10] exists between the actual transfer operation and visible industry use.

Mission Goals:

Mission-oriented laboratories have defined goals (e.g., reliable weapons, safe waste disposal, etc). Attempts to transfer technology to other industries detract from those goals and do not improve the viability of the labs.

Program Termination:

Successful transfer of technology terminates an R\&D program with no assurance of combining support for a researcher; $i . e .$, the researcher works himself out of a job.

Visibility:

Direct transfer of technology needed to meet mission goals is usually not considered a spinoff to industry; secondary applications of this technology may not be visible.

Not Technical:

The mechanics of transfer are difficult, expensive, and not usually technically challenging.

Solution Oriented:

Most scientists work in a disciplineoriented environment (solid state, shock wave, circuit design...), not a problemoriented environment. Thus, they have many solutions searching for problems.

No incentives exist to encourage transfer efforts. However, NASA's actions were legislated and the recent stevensonWydler Act [11] requires other federal agencies to make a conscientious effort to transfer technologies. 
Table 2. Mechanisms of technology transfer

\section{Most Effective}

\section{Spinoff Industry}

People Transfer to Industry

Joint Government-Industry Development and Test*

Government Development - Joint Test*

\section{Workshops}

Design Given to Industry

Publications and Presentations

Data Banks

*Frequently involve R\&D contracts from government to industry 
Table 3. Technology transfer processes

Stages of Development

Activity

Evaluation

Feasibility Development

System and

Economic

Math \& Lab

uild o Test

Verification

Transfer

Analyses

Models

Prototypes

Viable Prototype Design,

Industry Review Research

Lab \& Initial Evaluation

Manufacture

(continues to Define

Field Tests

and Test in

Commercial

end of pro- Boundary

gram)

Conditions

Advisory Panel Establish

Continued Involvement in Critique, Joint Tests, Potential Users

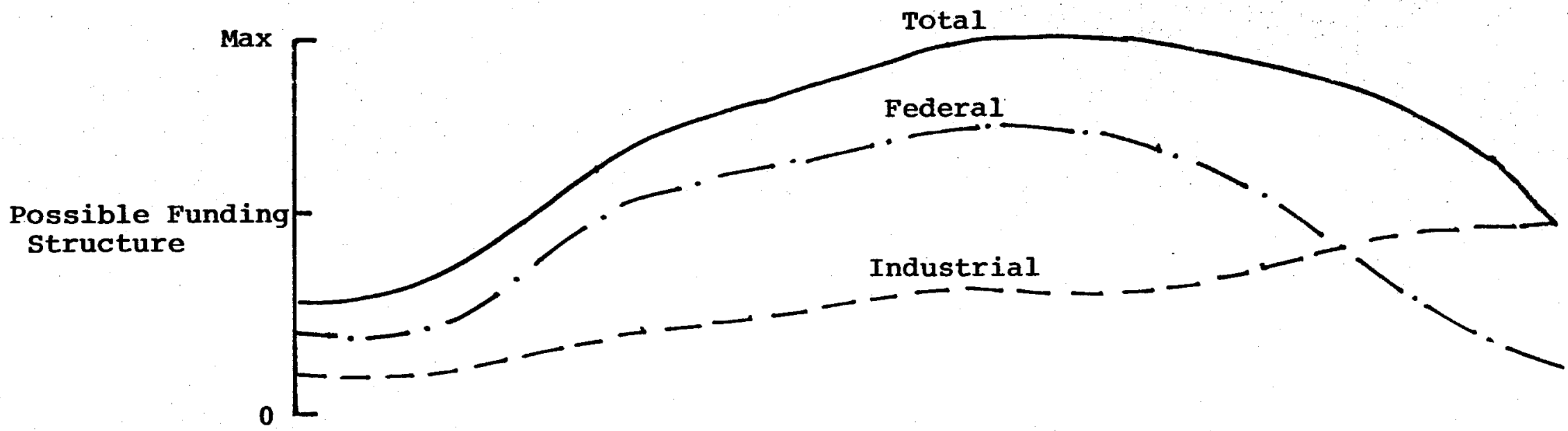

Typical Time

Scales

3-12 Months

6-12 Months 12-24 Months 6-24 Months

12 Months 
- Involve industry to understand commercial constraints and incentives

- Develop realistic schedules and goals

- Provide a rationale for shutting down a program if results cannot be justified

- Identify new areas for needed $R \& D$

Advisory panels of industrial personnel, plus academic and government experts provide semi-annual critiques of the programs, identify capabilities for joint endeavors and become personally involved in technologies of interest to their firms. None of the panel members have, nor expect contracts from the programs they advise. Industry has been most supportive in these interactions; advisory panel members who have supported sandia programs are listed in the appendix.

The funding sequences obviously vary with different projects, but it is important that projects be carried through the verification stage to assure transfer. The industrial funding has typically been to support the advisory panels, provide hardware or computer analyses specific to a given development, offer test or operational facilities to evaluate prototype equipment and supply the design and manufacturing support for building final hardware parts.

The following chapter summarizes the results of this methodology as applied to the geotechnology programs. 


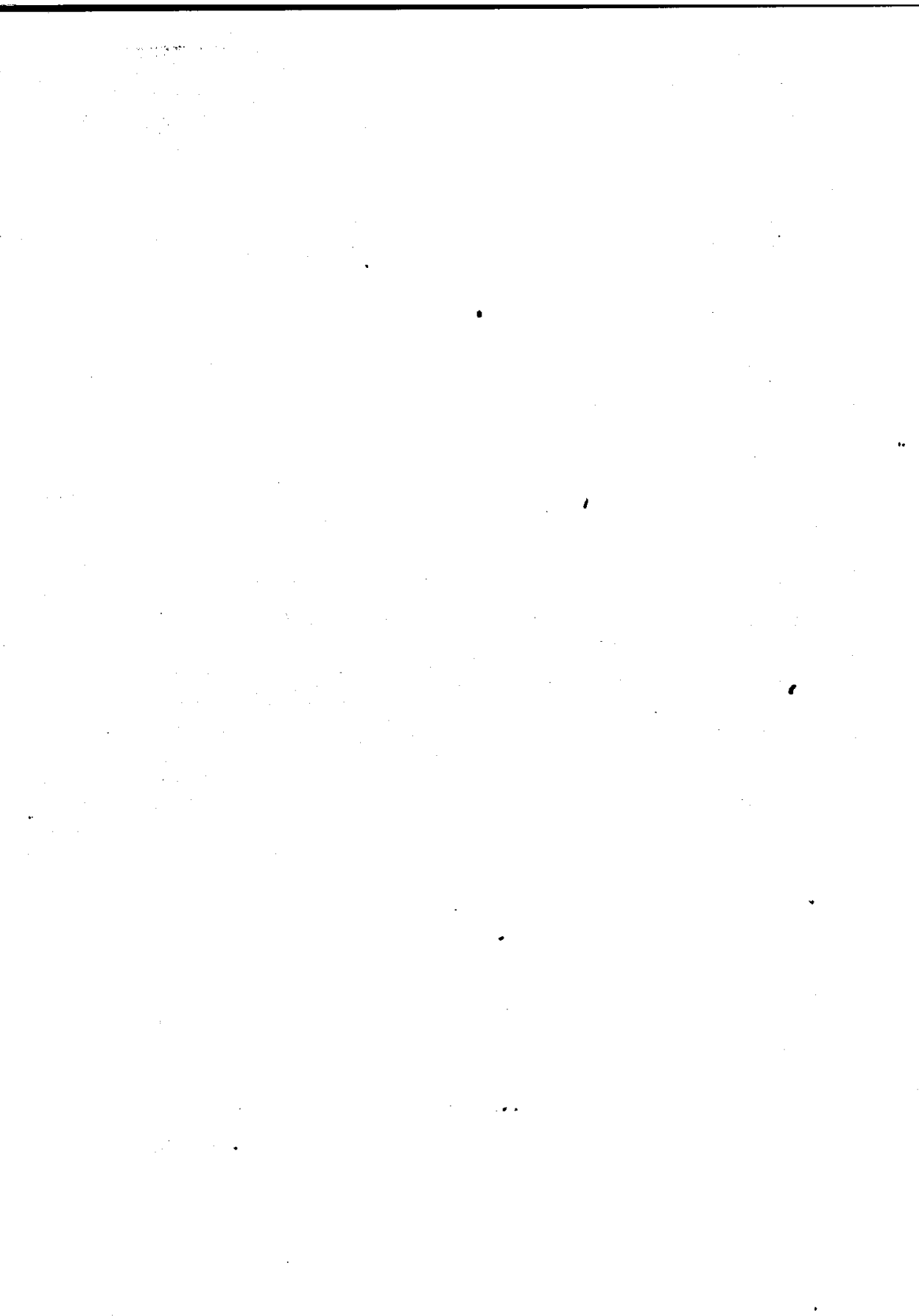

$+$

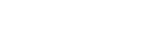




\section{GEO ENERGY TECHNOLOGY TRANSFER}

The effective transfer of technology occurs for many reasons and in several ways. A new concept -- hardware, computer program, material - that has an economic or market advantage, will be readily transferred. Such a transfer is obvious and easy to document. In some cases, a technology exists but industry is reluctant to pick it up because of the risk involved in modifying an existing plant or procedure. In the case where that technology exists at a federal laboratory, some directed research can catalyze adoption of that technology by industry. Since the technology does exist, the catalytic role of a laboratory may be difficult to quantify. When technology transferred consists of information or understanding, the transfer usually cannot be quantified. Such "inventions" have many fathers. Industrial personnel will also have been thinking along similar lines due to past contacts and the new concept is undoubtedly an evolution of many peoples' thoughts.

The following discussion is divided into these three categories: New Concepts, Risk Removal and Understanding. Again, there will be fuzzy boundaries between the areas with potential overlap. The results described are those by sandia researchers and contractors. In most outside contracts, a Sandia engineer or scientist was involved in research on one aspect of the project to maintain technical expertise in that area and contribute to the problem's solution.

\section{Technology Transferred}

\section{New Concepts}

Drilling, Completions and Mining: The following activities are all oriented to accessing resources including geothermal, oil and gas, coal and minerals.

Developed computer code to place polycrystalline diamond compact cutters on bit to optimize cutter life. Code now used by several major bit companies (Reed, PCI, Smith, Security).

- Developed process for diffusion bonding of PDCs to bit studs. Pressure coring Inc. is now applying this technology.

- Developed (with Hydronautics, Inc.) cavitating jets to enhance cutting and cleaning ability of bi-cone and tri-cone bits. Nozzles now available in Smith A-1 bits. 
- Developed and field tested new high-temperature drilling fluid using sepiolite clay. Formulation now available from NL Baroid.

- Developed. (with L'Garde) high-temperature elastomers for "0" ring applications. Now available through L'Garde, Precision Rubber, and Parker Seal Company.

- Developed (by Pacer Industries) high-temperature lubricant for roller-cone bearings. Marketed by Pacer Industries as Geobond ${ }^{\mathrm{TM}}$.

- Identified stabilizing acents and detergents for making aqueous foams stable at high temperature. Foamair is using results in foam drilling and Chevron in foam drive for enhanced oil recovery.

- Low invasion organic and water-based coring fluids developed for sampling depleted oil reservoirs are now in use by Pressure coring Inc. and Christensen.

Diagnostics: The major portion of diagnostics R\&D has been oriented toward instrumentation and analyses of in situ processes as enhanced oil recovery, oil shale retorting, underground coal gasification and stimulation, and to the evaluation of reservoirs by improved logging tools. Emphasis was also on high temperature electronics and capabilities.

- Quartz crystal transducer research led to new company, Quartex, and establishment of lab at schlumberger.

- New thick film resistor inks and discrete resistors for hybrid use at high temperature were developed and marketed by Cermalloy, Dupont, Craddock and Corning.

- Development of new circuits, materials, rotating transformer, acoustic transducers and other improvements are being incorporated into the borehole televiewer by simplec, the original manufacturer, and by Hot Hole Instruments, a new company established to provide high temperature field instrumentation. 
- Monitoring of in situ temperatures, pressures, flows and gas compositions is combined with retort model calculations, for oil shale retorting by Geokinetics and Occidental Oil shale.

- x-radiography for catalyst level monitoring developed, built and installed at HRI for coal liquefaction processing; Lummus and others requesting similar diagnostics and manufacturing technology being transferred to JR Sheppard.

Processes: Hardware or concepts to improve processes have been developed with major emphases on enhanced oil recovery and stimulation.

Development and test of a downhole steam generator for enhanced oil recovery is a new concept that has provided technology for five firms currently marketing generators; one of the firms, Enhanced Energy systems, is a new company.

Development of advanced packer designs for high temperatures resulted in marketing of new designs by Baker, L'Garde and Foster-Miller.

Developed and demonstrated the tailored pulse loading concept for creating multiple fractures for well stimulation. Currently offered as a commercial service through several companies.

\section{Risk Removal}

Drilling, completions and Mining:

Catalyzed design and use of bits using polycrystalline diamond compact (PDC) cutters. Prior to Sandia involvement, there were no commercial PDC bit manufacturers in the United States; now there are fifteen-plus companies marketing PDC bits (PCI, Stratabit, Davis Hicks, Security, Christensen, American Coldset, etc.).

Developed (with Drilling Research Labs) new seals and materials for tri-cone bits which enable survival at geothermal temperatures. Program cost shared with Reed Tool Company. 


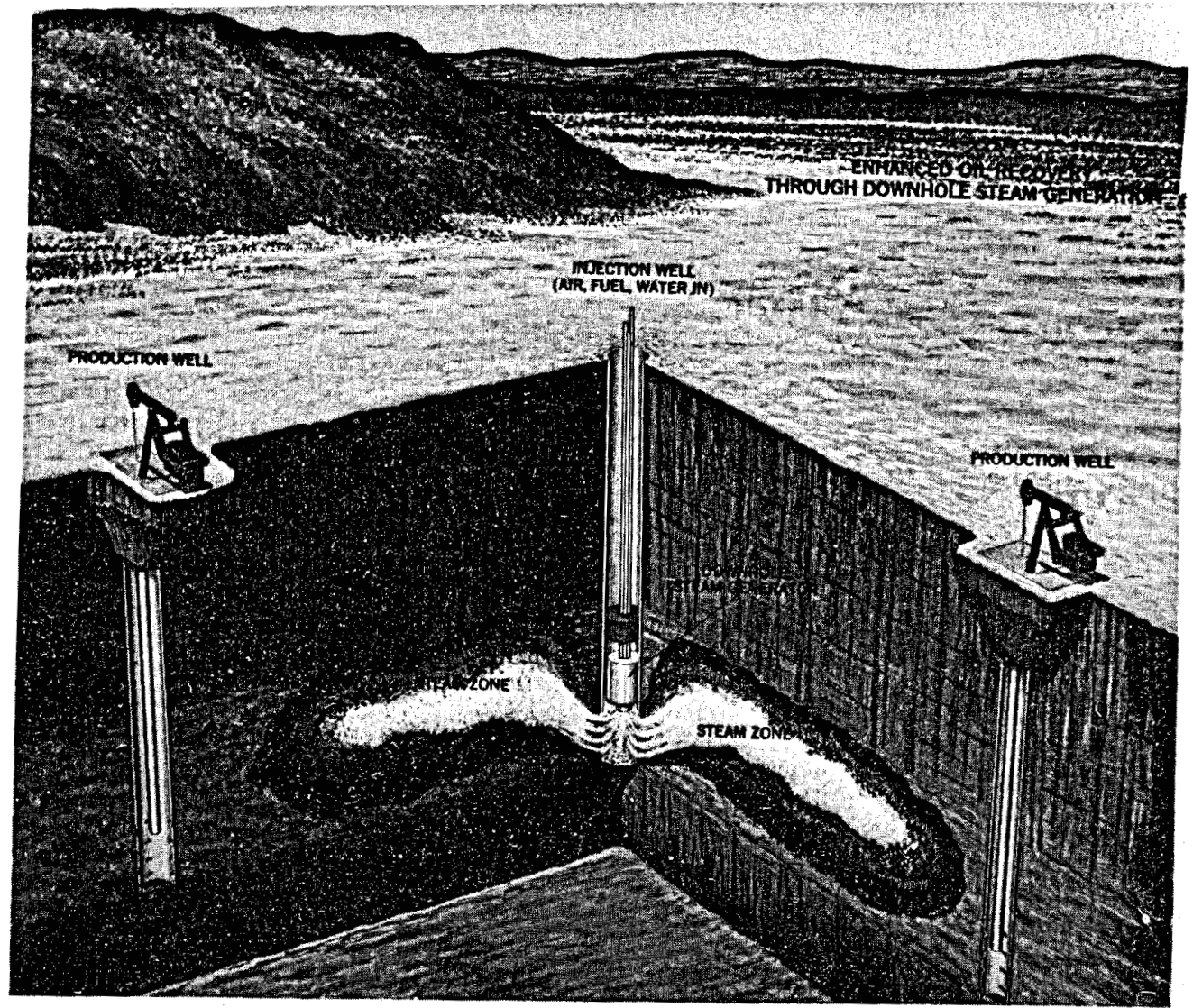

Figure 1. Downhole Steam Generator Concept -- Steam is used to recover heavy oils in oil reservoirs and tar sands. The downhole generator has advantages over surface boilers of high thermal efficiences, reduced air pollutants and more rapid recovery of oil. 


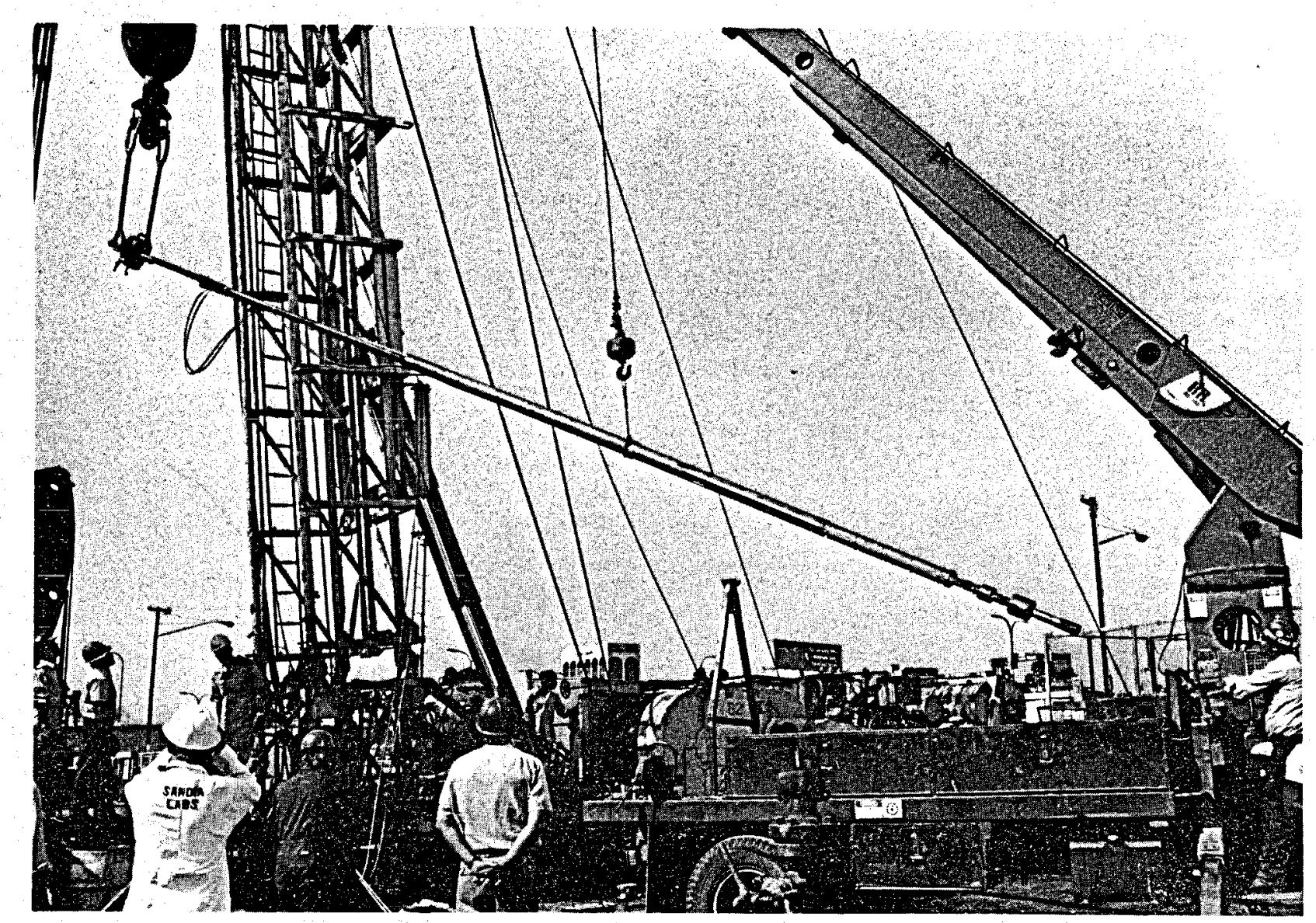

Figure 2. Downhole Steam Generator -- The generator is being installed in a well in conjunction with the city of Long Beach, California. 
- Redesigned (with DOWDCO) a pressure coring system for higher pressure use, to recover a longer core, with improved seals, and to incorporate a core orientation device; is in commercial use and resulted in establishment of a new company, Pressure coring Inc.

\section{Diagnostics:}

- Developed $275^{\circ} \mathrm{C}$ hybrid circuitry for: voltage regulators, line drivers, pulse stretchers, and voltage-to-frequency converters. Products are now available from Teledyne-Philbrick.

- Developed a multiplexer (GE marketing) and an op-amp (Harris marketing) for use to $275^{\circ} \mathrm{C}$ in downhole logging tools.

- Demonstrated (with Gearhart Industries) the application of hybrid microcircuit technology to logging tool instrumentation; adopted for use by Gearhart and Schlumberger.

- Design changes on clock bearings and lubricants now used in slick line logging tools transferred to Kuster Tool and Geophysical Research; also a new company, Thermodurics, established.

Developed several advanced instrumentation techniques for in situ process monitoring; the tilt meter concept for determining fracture propagation direction was jointly developed by and currently marketed by Fracture Technology, Inc., and others.

\section{Processes:}

Verification of insulation effectiveness on downhole tubular goods resulted in a new injection string insulation system by GE and catalyzed work on new downhole pipe insulation concepts by several companies.

Identification of catalytic effects by pyrite and other minerals in coal provided major impetus to DOE programs in disposable and slurry phase catalysts. Being evaluated by Gulf, Exxon and Mobil. 


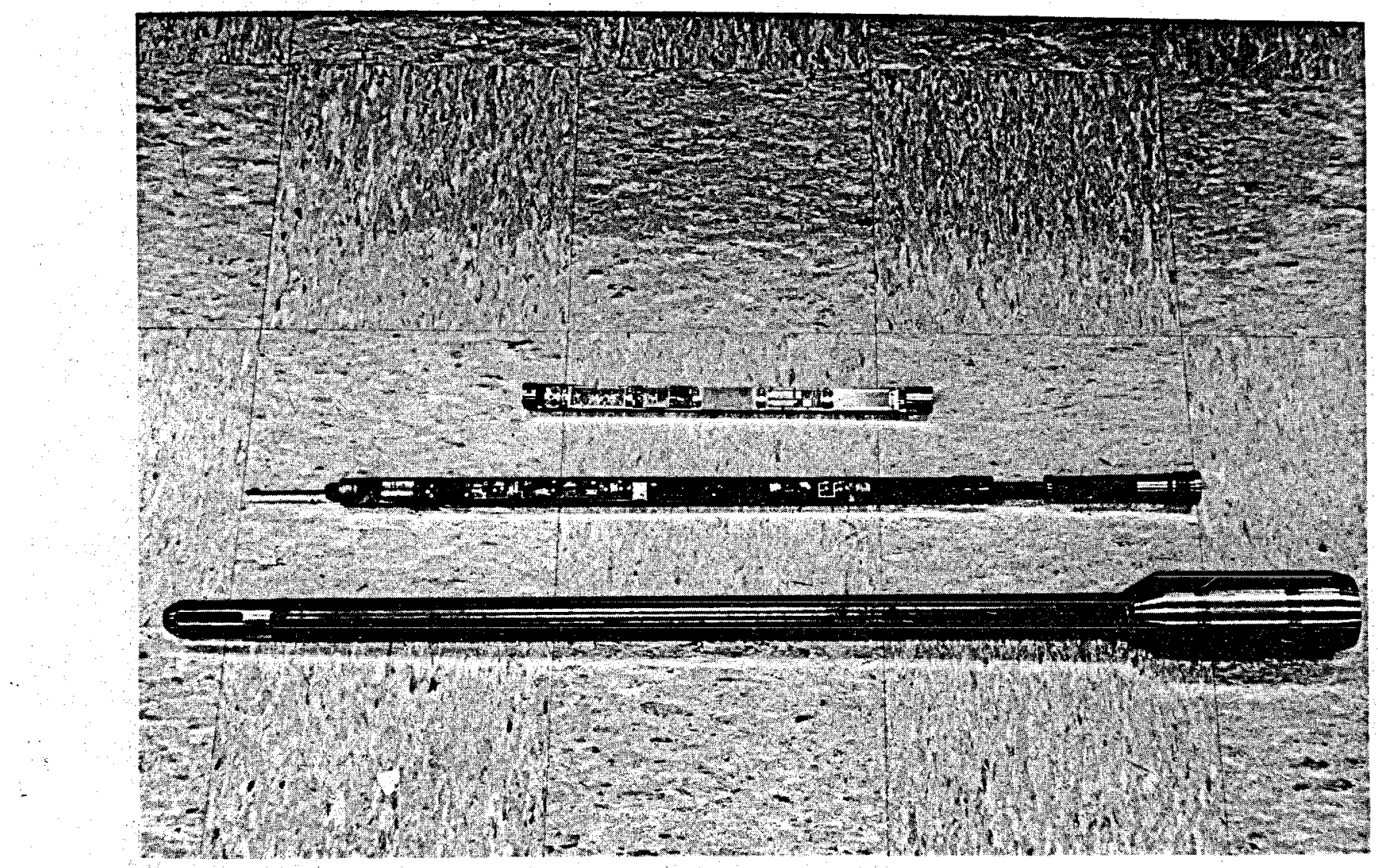

Figure 3. High Temperature Electronics -- The high temperature hybrid microcircuits (upper unit) operate to $275^{\circ} \mathrm{C}$, are more compact than conventional circuitry. (middle unit) and have high reliability. These circuits are packed in a Gearhart temperature logging tool (lower unit). 


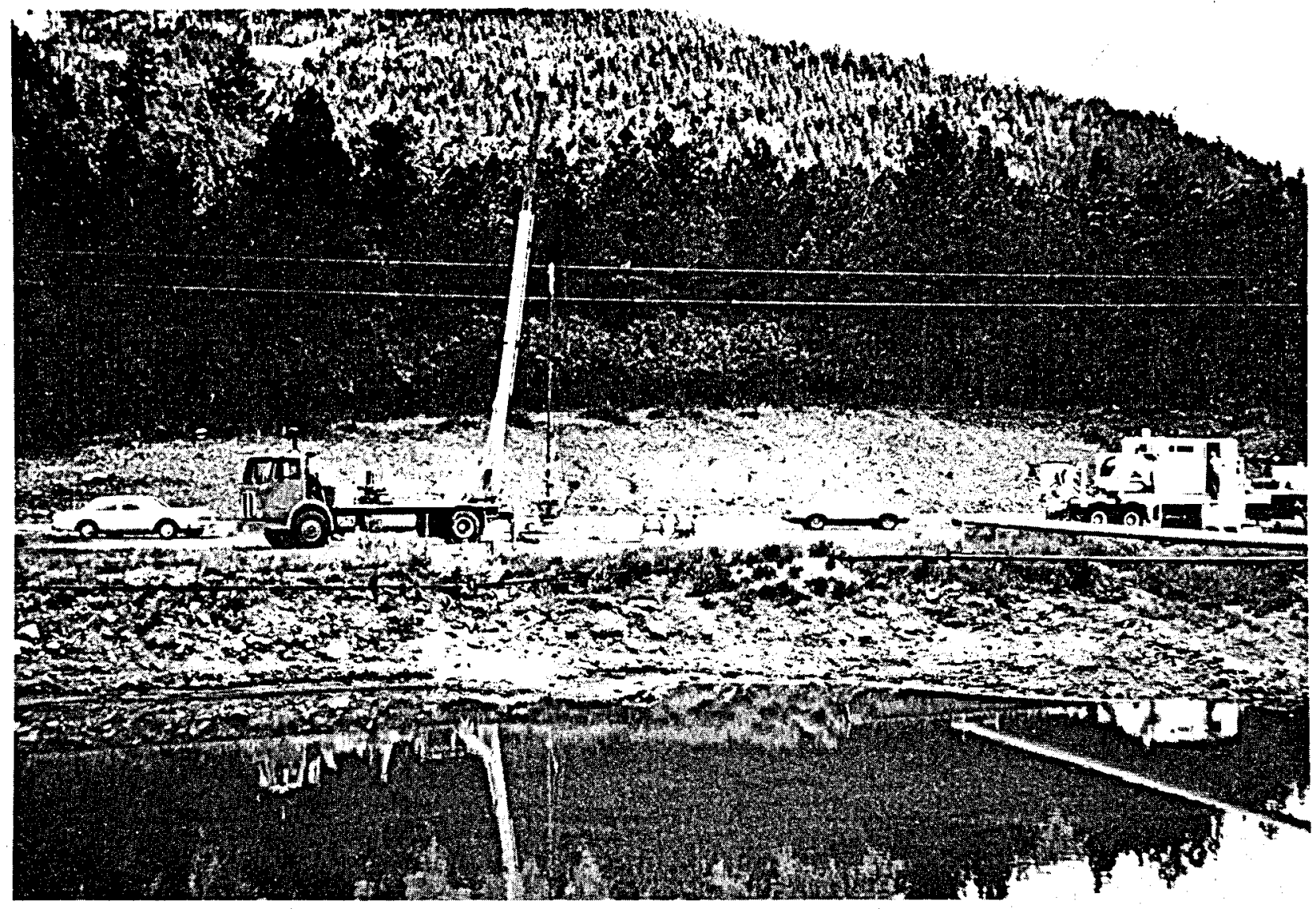

Figure 4. Logging a Geothermal Well -- Operation of the high temperature electronics was confirmed by logging union's geothermal wells. 


\section{Information}

\section{Drilling, Completions and Mining:}

Software for analyzing casing stress and failure in geothermal environments adapted by Union and Aminol.

\section{Diagnostics:}

- Improved performance of Corioles mass flow meters by changing tube radii being incorporated in new models by Micromotion, Inc.

\section{Processes:}

- Verification of low temperature coal dissolution reactions enhancing shift of all direct liquefaction processes to "two-stage" processes.

- Measured residence times and catalyst deactivation rates in $\mathrm{H}$ coal $\mathrm{PDU}$; resulted in changes in operating procedures and data interpretation for $\mathrm{H}-\mathrm{coal}$ process.

- Development of novel, slurry phase catalysts initiated research on advanced catalysts for twostage IIquefaction at Amoco, American Cyanamide and Lummus/Cities Service.

- Identification of the formation and loss of low boiling hydrocarbon fuels in oil shale retorting: now being recovered by Geokinetics.

\section{Technology with Potential for Transfer}

Extensive interactions with advisory panels and industry assures that many program aspects are in the process of being transferred. The technologies Iisted in this section have received industrial interest and many should be transferred within a year.

\section{New Concepts}

Drilling, Completions, and Mining:

Designed and built high-temperature/high-pressure viscometer for evaluating drilling fluids at geothermal conditions. Prototypes now being used by Texas Tech University. Industry requests from shell, Chevron, and Union. 
Application of an inertial navigation system to the spatial mapping of wellbores. Field test of prototype tool scheduled for February 1982. Exxon and Scientific Drilling Controls currently developing hardware; Sperry sun and Eastman Whipstock following. Patent problems delaying transfer of electronic design, packaging techniques and associated software.

Design (with Engelhard) of inert gas generator which cleans diesel exhaust gas for use as a substitute for air (when air drilling) to reduce drill pipe corrosion. Companies such as Western Air Drilling and Foster-Miller Associates considering marketing.

Waterjet descaling system for cleaning scale for geothermal wells. Uses cavitating jets, minimizing casing damage and permitting well to flow while being cleaned. Also being considered for underreaming geothermal wells to increase productivity.

Waterjet drill for providing horizontal wellbores in coal seams for methane drainage, in situ gasification or other processes.

Reamer bits modified to use polycrystalline diamond compact cutters and Sandia developed wear sensors (to indicate hole gage) to be evaluated in field tests.

Completed development of roof bolt drill bits which significantly improve penetration rates and bit life over conventional bits; being evaluated by General Electric, Kennametal and Bendix.

\section{Diagnostics:}

Development of a long-life, high-power electrical switching device for use at elevated temperature. Sprytron tube is being modified to operate as SCR for primary use in cement-bond logging tool.

Development of a $300^{\circ} \mathrm{C}$ sheathed monocable which is resistant to geothermal environment. Halpen. Engineering to deliver 15,000 feet of sheathed monocable to Sandia in March 1982. Other private companies have initiated development and marketing activities.

Downhole, periodic seismic source for in situ, geophysical exploration of geothermal and oil or gas reservoirs, mineral resources and in situ processes. 
- Development of high temperature probes for monitoring convection in magma bodies being considered for use in monitoring steel making processes.

- Magnetic tracer for process diagnostics requested by Lummus and Exxon.

- Electrical potential and borehole seismic methods developed for determining fracture orientation and geometry is being documented and being considered for adoption by industry.

- Remote, underwater seismic equipment with an automated acoustic communications link has been developed and successfully used; detailed designs being disseminated to industry.

\section{Processes:}

- Titanium Diboride hard coatings as valve trim for Air Products and Exxon; for hardened thermocouple wells by Stearns-Rogers.

- Currently developing and demonstrating technologies to recover gas from lenticular, tight gas sand reservoirs in an extensive field experiment in Colorado; joint industry-Sandia effort constantly transferring technology.

\section{Risk Removal}

\section{Drilling, Completions and Mining:}

Seals capable for sealing high-speed turbine/motor bearing packages at geothermal conditions. The HTCR-SF design has operated for 200 hours under laboratory conditions.

- Guidelines for the design of hydraulic configurations to improve cutter cooling and bottomhole cleaning being assessed by industry.

- Developing understanding of coal and rock cutting energetics through laboratory tests and finite element analyses for advanced rock and coal cutting systems. 
1

\section{Processes:}

Research on low temperature coal liquefaction mechanisms and catalyst deactivation processes originated a concept of low severity coal liquefaction now being considered for $\mathrm{H}-\mathrm{coal}$ and the new two-stage liquefaction processes. 
The unclassified, energy related, industry oriented Department of Energy Programs at Sandia have provided an excellent mechanism to effectively transfer many of our technologies from government to industry. The strong research base in insitu diagnostics (from weapons testing), transport processes and materials for hostile environments is being coupled with a directed systems approach to get new concepts into the private sector. A recent conference [17] on high temperature electronics, after all federal funding on the project had ceased, attracted over 350 attendees with industry asking to present papers and display new wares. This termination of a geothermal logging instrumentation program signaled the advent of a new industrial move into high temperature electronics for use in the logging of deep gas wells and geothermal resources, for monitoring controls and environments inside nuclear reactor containment vessels, for warning of jet flameout in aircraft engines and many other new applications.

Details of the transferred technology, presented in the previous text, can be summarized in facts:

- Five new companies have been established

based on these technology developments.

- Over thirty engineers and scientists, involved in these energy programs, have joined industry at industry's initiative.

- A new perspective of electronics use in hostile environments and for describing in situ processes has been initiated.

- Capabilities were made available to monitor and evaluate national problems as coal mine fires in Pennsylvania and Colorado, volcanic hazards at Mt. St. Helens, and oil storage problems at the Strategic Petroleum Reserve sites.

The technology transfer has been largely from the base developed in the weapons programs to the energy sector, but transfer has also occurred in the other direction. Work on special crystallographic cuts of quartz crystals to minimize temperature effects for the evaluation of geopressured resources has resulted in quartz tuning forks for weapon's timer applications. Work initiated on gallium phosphide and arsenide semiconductor devices for high temperature diodes is being applied to use in radiation hardened circuits for weapons. 
The success of these programs reinforce the lessons of past technology transfer studies that person-to-person interactions are essential to effective transfer. These interactions are generally well supported by industry as evidenced by the advisory panels and many joint programs. As the energy programs phase out of the federal budgets, new methods will have to be developed to maintain the existing communications. Unfortunately, these new methods have not yet been identified. 
REFERENCES

[1] M. J. Kelly, Bell Laboratories Record, "The Transistor Ten Years of Progress," p. 190 (June 1958).

[2] Electronic Design 24, p. 66 (November 23, 1972).

[3] G. W. Hough, Technology Diffusion, Lomond Books, Mt. Airy, Maryland (1975).

[4] D. E. Cunningham, J. R. Craig and T. W. Schlie, Editors, Technological Innovation, Westview Press, Boulder, Colorado (1977).

[5] W. H. Gruber and D. G. Marquis, Editors, Factors in the Transfer of Technology, MIT Press, Cambridge, Massachusetts (1969).

[6] 1980 IEEE Engineering and Management Conference Record, November 12-14, 1980, Wakefield, MA.

[7] Showcase for Technology, October 27-28, 1981, Albuquerque, New Mexico.

[8] F. I. Robinson, "NASA Technology Transfer," from the Technology Transfer Division, P. O. Box 8757, BaltimoreWashington International Airport, Maryland (1981).

[9] National Academy of Engineering, Reference 4, "Technology Transfer and Utilization Recommendations for Redirecting the Emphasis and Correcting the Imbalance," p. 55.

[10] E. B. Roberts in Reference 5, "Entrepreneurship and Technology," p. 219.

[11] Public Law 96-480 [S. 1250], Stevenson-Wydler Technology Innovation Act of 1980, U.S. Senate (October 21, 1980).

[12] R. L. Rudman, EPRI Journal, 6 (9), "Research Oriented Toward Applications," p. 2 (November 1981).

[13] J. Douglas, EPRI Journal, 6(9), "Technology Transfer: The Ultimate Measure of R\&D," p. 6 (November 1981).

[14] A. Dupont in Ref. 6, "Technology Transfer and Industries," p. 129 .

[15] T. Burns in Ref. 5, "Models, Images and Myths," p. 11.

[16] A. H. Teich and W. H. Lambright in Ref. 4, "Federal Laboratories and Technology Transfer: An Interorganizational Perspective," p. 431. 
[17] High Temperature Electronics Instrumentation Conference, December 7-8, 1981, held at the Marriott at the Astrodome, Houston, Texas, sponsored by Sandia National Laboratories, in conjunction with the U.S. Department of Energy, IEEE, and the University of Houston. 
APPENDIX A

ADVISORY PANELS

Geothermal Technology Program Industry Advisory Panel

Tom Anderson, IMCO Services

W. E. Bingman, Drilling Engineering Advisor, shell oil Company Larry Diamond, Vice President, Technical Services, Dyna-Drill John E. Fontenot, Manager, Mechanical Engineering, NL Petroleum Services

Dr. Melvin Friedman, Professor of Geology, Texas A\&M University Wilton Gravley, Engineering Associate, Mobil Research and Development Corp.

Earl G. Hoff, Development and Operations Director, Phillips Petroleum Company

Jim Kingsolver, Manager, Geothermal Operations, Smith Tool

James W. Langford, Manager, Research, Security Division, Dresser Industries, Inc.

Harvey E. Mallory, Assistant to President, Field Operations, Loffland Brothers Company

Gene Polk, NL Baroid

Delbert E. Pyle, Manager of Operations, Union Geothermal Division, Union 011 Company of California

John C. Rowley, Field Operations and Engineering, Los Alamos National Laboratory

William D. Rumbaugh, Project Engineer, Research and Development, Otis Engineering

Dwight Smith, Halliburton

Tom Warren, Amoco Production Company

Consultant Panel for Offshore and Frontier Technologies

Junius Allen, ARCO

Gary Boubel, ARCO

Paul Aagaard, Chevron

Robert Haring, Exxon

F. P. Dunn, Shell Oil Company

Paul Durning, Union Oil

Paul Teleki, U. S. Geological Survey

Louis E. Garrison, U. S. Geological Survey 


\section{High Temperature Logging Instrumentation Panel}

William R. Berry, Occidental Exploration and Production Bruce Blackman, Electrical R\&D Department, Halliburton Services R. A. Broding, Amoco Production Company Research Center Jan Brown, Schlumberger Doll Research John T. Byrne, Interstate Electronics Tom Campbel1, Campbell Consulting

Stan Coombs, Pacific Resources Management

Carl Dodge, Halliburton Services

Dick Dunlap, Aminol USA, Inc.

John Herrgott, Hewlett Packard

Bob Hoard, Phillips Petroleum Company

Gus Hoehn, Mobil R\&D Corporation

W. Scott Keys, Research Hydrologist, U.S. Geological Survey Jack Kusters, Hewlett Packard

Donald R. Lindsay, Occidental Geothermal, Inc.

Bob Macy, Manager of Geothermal Planning and Technology

Assessment, Sunoco Energy Development Company

Bob Mayer, Gearhart Owen Wireline Services

Bob McElwrath, United Wireline

Joseph F. Petko, Dresser Atlas

Howard Schaible, Rochester Corporation

Ron Schroeder, The Berkeley Group

Dr. Richard S. Simpson, Department of Electrical Engineering, University of Houston

Al Skellie, Schlumberger Well services

Dan Stalmack, Senior Research Geophysicist, Chevron Research, Inc.

Calvin O. Vogt, President, Geophysical Research Corporation

B. F. Wilson, Systems Manager, Research and Engineering, Dresser Atlas

Joe Zemanek, Mobil R\&D Corporation

Multi-Well Technical Review Panel

Tom Muecke, Exxon Production Research

Ralph Veatch, Amoco

Randy Saucier, Shell oil

Lincoln Elkins, Sabio

John Fitch, Mobil

Glen Martin, Arco

Amil David, Superior Oil Company 
Enhanced Oil Recovery Advisory Group

H. R. Anderson, U. S. Department of Energy George Stosur, U. S. Department of Energy

A. J. Leighton, U. S. Department of Energy

G. W. Dean, U. S. Department of Energy

T. R. Blevins, Chevron

L. L. Handy, University of Southern California

E. J. Hanzlik, Getty Oil

R. C. Ellis, Completion Technology Company

R. T. Meldau, Husky Oil

Steve Pursley, Exxon Production Research

E. D. Verink, University of Florida

Alan R. Hirasuna, L'Garde

GRI - Unconventional Natural Gas Project Advisory Group

Paul Chase, Public Service Electric and Gas Co. Robert Christopher, United Gas Pipeline Company Ralph Coates, Mountain Fuel Supply

Nick Skorski, Michigan Wisconsin Pipeline Company Robert Forrest, Columbia Gas system Service Corp. Ernest Geer, Transco Energy Co. David Giebelhaus, Lone Star Gas Co. Forrest Lewis, Texas Gas Transmission Corp. John Moore, Consolidated Natural Gas Services Corp. Edgar Rassinier, Trunkline Gas Co.

Alfred Schlemmer, Texas Eastern Gas Pipeline Corp. Stanley Whitford, Natural Gas Pipeline Co. of America Charles Nathan, New Mexico Energy Institute 
APPENDIX B

MAJOR PUBLICATIONS

$\underline{\text { Coal }}$

L. C. Bartel, T. L. Dobecki, et al., "Results of the Characterization of an In Situ Coal Gasification site in the state of Washington," Proceedings of the Sixth Underground Coal Conversion Symposium, Afton, Oklahoma, 1980.

B. E. Bader and R. E. Glass, "The Role of Site Characteristics in the Control of Underground Coal Gasification," Proceedings of the Fifth Symposium on Instrumentation and Control for Fossil Energy Processes, 1981.

R. E. Glass, "Applications of Reservoir simulation to In Situ Coal Gasification," SAND80-2579, 3/81 (to be published in In Situ).

S. L. Love and K. M. Timmerman, "Testing of a Water Jet system for Drilling Horizontal Holes in Coal," Proceedings of the Seventh Underground Coal Conversion Symposium, Fallen Leaf Lake, California, 1981.

\section{O11 and Gas}

P. S. Lysne, J. S. Yu, C. N. Vittitoe, and L. E. Duda, "Dielectric Log Interpretation: Probe Response and Dielectric Properties of Rocks," 22nd Annual Meeting of SPWLA, Mexico City, June 23-26, 1981 .

D. A. Northrop, et al. "DOE Western Gas Sands Project's Mult1-Well Experiment," Proceedings of the 1981 SPE/DOE Symposium on Low Permeability Reservolrs, Denver, Colorado, May 1981.

N. R. Warpinski, et al., "In situ stress: The Predominant Influence on Hydraulic Fracture Containment," Proceedings of the 1980 symposium on Unconventional Gas Recovery, Pittsburgh, Pennsylvania, May 1980.

R. I. MCNeill, S. Green, "In situ Determination of strength Parameters of Marine Soils, Sandia Laboratories Report SAND80-0693, June 1980. 
R. I. MCNeill, "Derivation of an Approximate Equation for Estimating Shear Strength of Cohesive Materials from Penetrator Deceleration," Sandia National Laboratories Report SAND81-1364, June 1981.

R. L. McNeill, "An Approach for Estimating Soil Attachment During Penetration Events, Sandia National Laboratories Report SAND80-2667, May 1981.

R. L. Fox, et al., "DEEP STEAM: Development of Downhole steam Generation Systems and Injection String Modifications for DEEP STEAM Injection," 5th DOE Annual Symposium on Enhanced Oil and Gas Recovery, Tulsa, Oklahoma, 1979.

B. E. Bader, R. L. Fox, and J. J. Stosur (DOE), "The Potential of Downhole Steam Generation for the Recovery of Heavy Oils," lst International Conference on the Future of Heavy Crude and Tar Sands, Alberta, Canada, 1979.

N. R. Warpinski, et al., "High Energy Gas Frac: Multiple Fracturing in a Wellbore," Proceedings of the 20 th U. S. Symposium on Rock Mechanics, Austin, Texas, 1979.

R. I. McNeill, "Enhancement of Geophysical Soil Profiles Using Instrumented Marine Sediment Penetrators," Proceedings of Offshore Technology Conference, OTC 3526, 1979.

\section{Synthetic Fuels}

P. J. Hommert and C. E. Tyner, "Model Capabilities for In Situ oil Shale Recovery," Journal of Energy Resources Technology, June 1981 .

J. T. Schamaun, "Lumped Mass Modeling of Overburden Motion During Explosive Blasting," Proceedings of the 14th Oil Shale Symposium, Golden, Colorado, 1981.

C. E. Tyner, "In Situ Borehole Retorting of Oil Shale," Proceedings of 15th IECEC, Seattle, Washington, August 1980.

R. R. Boade, M. E. Kipp and D. E. Grady, "Dynamic Fracture and Fragmentation of Oil Shale: Application of a Numerical Model to a Blast Design," Proceedings of the 14th Oil shale Symposium, Golden, Colorado, 1981.

G. S. Davidson and P. J. Hommert, "Instrumenting and Evaluating Large Scale In Situ Experiments," SAND81-0968C, Sandia

National Laboratories Report, 1981. 
D. E. Barnes, T. W. H. Caffey, and G. S. Davidson, "A Buried Telemetry System for In Situ Energy Extraction," presented at the Instrument Society of America, January 16, 1980.

B. Granoff and P. Montano, "Mineral Matter Effects in coal Conversion," Conference on the Chemistry and Physics of coal Gasification, West Virginia University, June 2-4, 1980.

D. G. Sample and M. G. Thomas, "The Tagging of an H-coal PDU Run," 1980 Symposium on Instrumentation and Control for Fossil Energy Processes, Virginia Beach, Virginia, June 9-11, 1980.

M. G. Thomas, D. G. Sample, J. L. Floyd and T. D. Sinclair, "Selectivity of Catalysts Towards Coal-Derived Products," Northwest Regional ACS Meeting, Salt Lake City, Utah, June 1980 .

T. D. Padrick, "The Effect of Mineral Matter on Coal Gasification," Fall Meeting of the ACS, Division of Fuel, Las Vegas, Nevada, September 1980.

M. G. Thomas, "Catalysts in Coal Liquefaction," 8th Energy Technology Conference and Exposition, Washington, DC, March 9-11, 1981 .

M. G. Thomas, T. C. Bickel, and B. Granoff, "The Effects of Catalysts on Short Contact Time coal Liquefaction," ACS Meeting, Division of Fuel, Atlanta, Georgia, March 1981.

F. V. Stohl and B. Granoff, "The Relationship Between the Properties of Iron Sulfides and Their Catalytic Activity," 90th National AiChE Meeting, Houston, Texas, April 5-9, 1981.

D. G. Sample, M. G. Thomas, and J. K. Iinn, "The Design and Use of Density Gauges for Fossil Energy Processes," 1981 Symposium on Instrumentation and Control for Fossil Energy Processes, San Francisco, California, June 8-10, 1981 .

M. G. Thomas and T. C. Bickel, "Catalyst Residence Time Distribution in the H-Coal PDU," 88th National Meeting of the AIChE, Philadelphia, Pennsylvania, June 8-12, 1980.

\section{Geothermal}

J. T. Finger, "Laboratory Testing of Percussion Drills for Geothermal Applications," Geothermal Resources Council, September 1980.

P. B. Rand, "Aqueous Foams for Geothermal Drilling Fluids -Surface Screening," Geothermal Resources Council, September 1979. 
C. C, Carson, Y, T, Iin, "Geothermal Well Cost Sensitivity Analysis," Geothermal Resources Council, september 1980.

F. E. Heard, "Upgrading the Acoustic Borehole Televiewer for Geothermal Fracture Mapping, Geothermal Resources Council, September 1980 .

B. L. Draper, D. W. Palmer, "Extension of High Temperature Electronics," IEEE Trans. on Components, Hybrids and Mfg. Technology, December 1979.

J. A. Coquat and A. F. Veneruso, "Technology Development for High Temperature Logging Tools, "Transaction of the 12th Annual Logging Symposium sponsored by the Society of Professional Well Log Analysts, June 1979.

J. I. Colp and H. M. Stoller, "The Utilization of Magma Energy -- a Project Summary," Proceedings, Second CircumPacific Energy and Mineral Resources Conference, July 1978.

D. L. Douglass, P. J. Modreski, and J. T. Healey, "The Corrosion of Some Pure Metals in Basaltic Lava at $1150^{\circ} \mathrm{C}$, ABS, Proceedings of Hawaii Symposium on Intraplate Volcanism and Submarine Volcanism, Hilo, Hawaii, July 1979.

H. C. Hardee, "Heat Extraction from Magma Bodies," Ibid.

J. F. Hermance, D. W. Forsythe, and J. I. Colp, "Summary of Geophysical Sensing Experiments on Kilauea Iki Lava Lake, Ibid.

T. M. Gerlach, "The Gas Phase of Tholeiitic and Alkaline Magmas," ABS., Abstracts with Programs, 1979 Annual Meeting, Geolg. Soc. Am., San Diego, California, November 1979.

E. J. Graeber, P. J. Modreski, and T. M. Gerlach, "Compositions of Gases Collected During the 1977 East Rift Eruption, Kilauea, Hawaii," J. of Volcanology and Geothermal Research 5,1978 .

\section{Subsidence}

D. E. Munson and H. J. Sutherland, "The Empirical and Analytic Approaches to Subsidence Prediction," Proceedings of the Polish-American Conference on Ground Control in Room-andPillar Mining, Southern Illinois University at Carbondale, August 6-8, 1980 .

N. G. W. Cook, M. Hood, and J. Daemon, "Surface Subsidence Resulting from Underground Coal Ming," Interim Report No. 1 for Contract No. 62-0200, Department of Material Science and 
Mineral Engineering, University of California, Berkeley, October 15, 1980. 


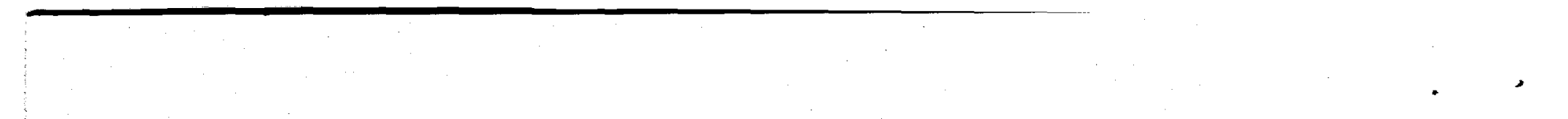


APPENDIX C

EXHIBITS 
OIL AND GAS RESEARCH AND DEVELOPMENT

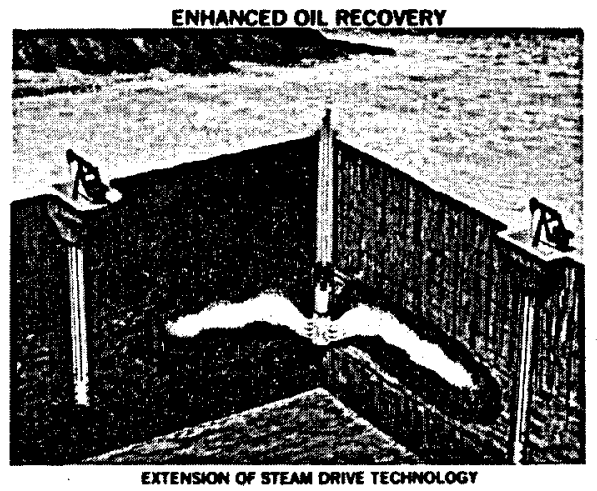

UACONVENTIONAL GAS PESOURCES
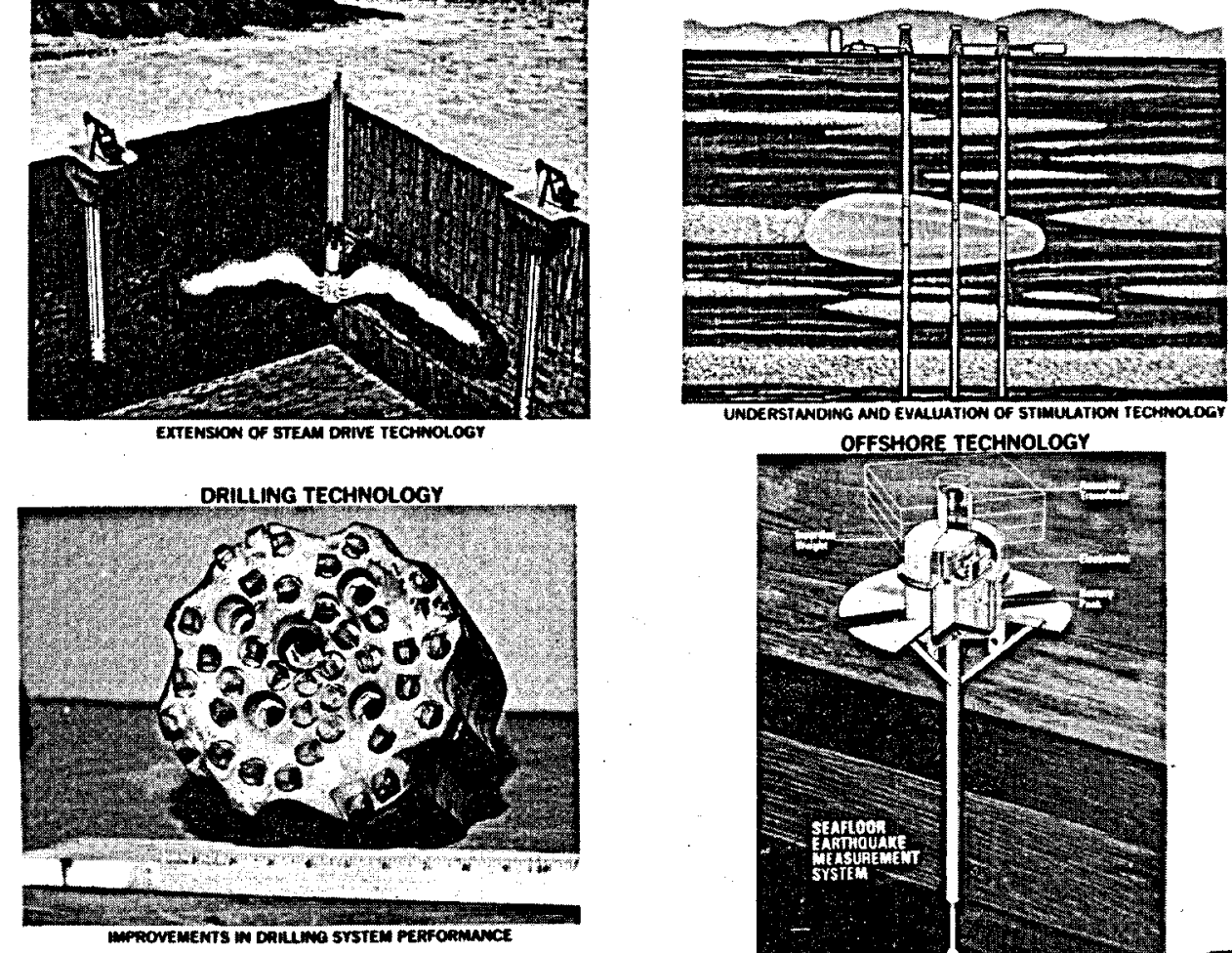

OFFSHORE TECHNOLOGY

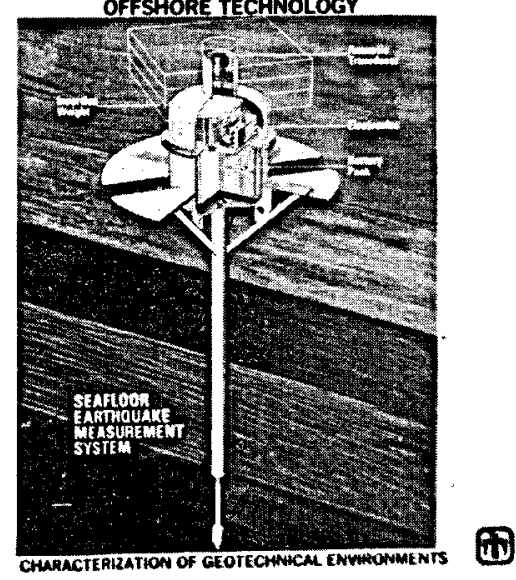

SANDIA OIL AND GAS RESEARCH AREAS 


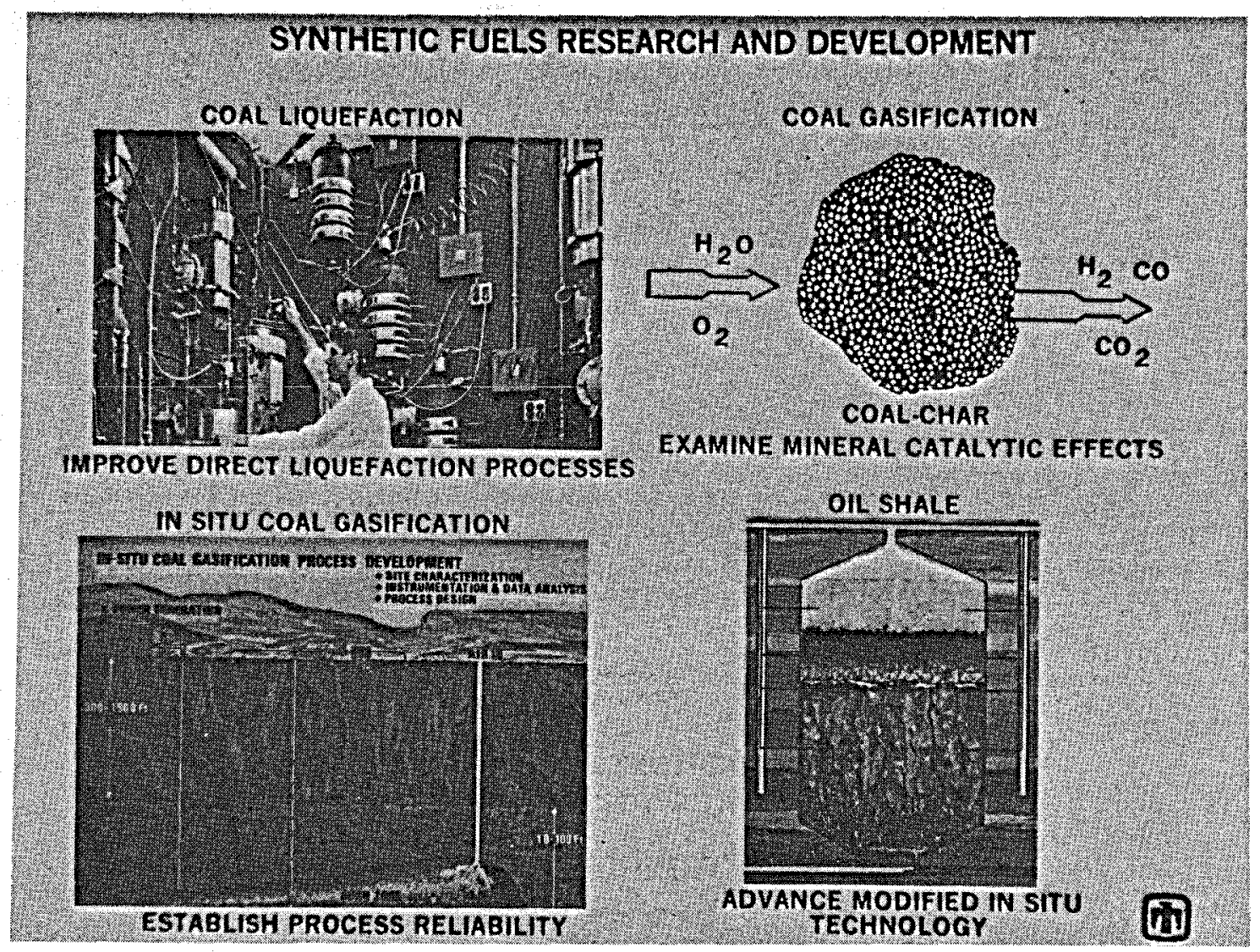

SANDIA RESEARCH AREAS IN SYNTHETIC FUEL DEVELOPMENT 


\section{GEOTHERMAL TECHNOLOGY PROGRAM \\ DEVELOPMENT OF ADVANCED DRILLING, COMPLETION, AND LOGGING SYSTEMS FOR ACCESSING THE GEOTHERMAL RESOURCE}

ROCK MECHANICS

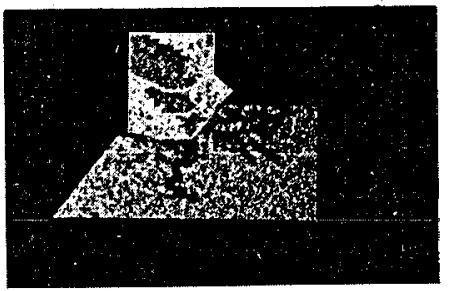

MIGH SPEED

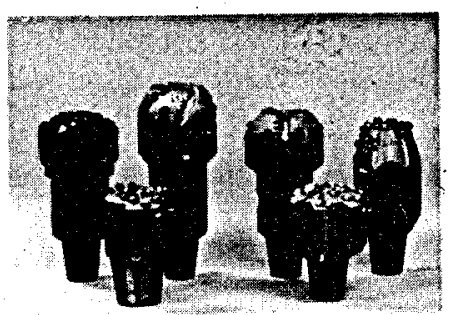

CAVITATION
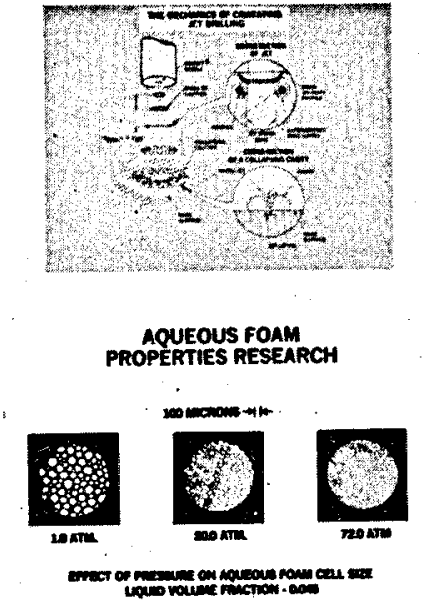

闲 Sandia National laboratories
MELAORE

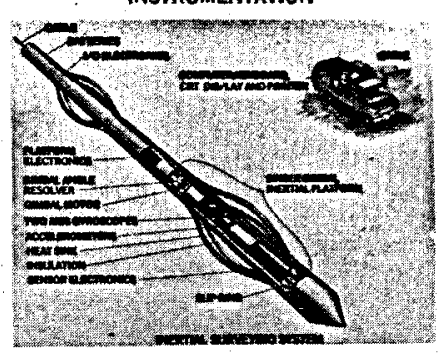

LOST CIRCULATION
MATERLAL EVALUATION

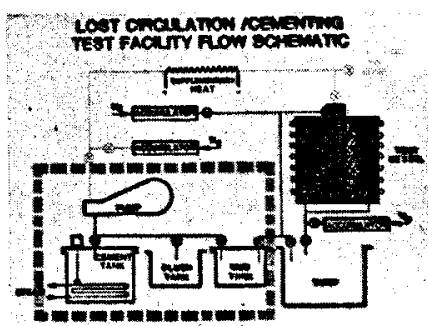

GEOTHERMAL TECHNOLOGY RESEARCH AREAS 


\section{MAGMA ENERGY RESEARCH}

GOAL: TO DETERMINE THE SCIENTIFIC FEASIBILITY OF MAGMA ENERGY UTILIZATION

\section{ACTIVITIES: LAVA LAKE FIELD EXPERIMENTS LABORATORY CONVECTION EXPERIMENTS IN FURNACES MAGMA CHARACTERIZATION STUDIES}

\section{FYB1 ACCOMPLISHMENTS}

DRILLED INTO $1100^{\circ} \mathrm{C}$ MELT AND SUCCESSFULLY OPERATED FIRST OPEN HEAT EXCHANGER

IN MOLTEN BASALT

MEASURED SEISMIC TRANSMISSION SIGNATURE THROUGH A MELT LENSE
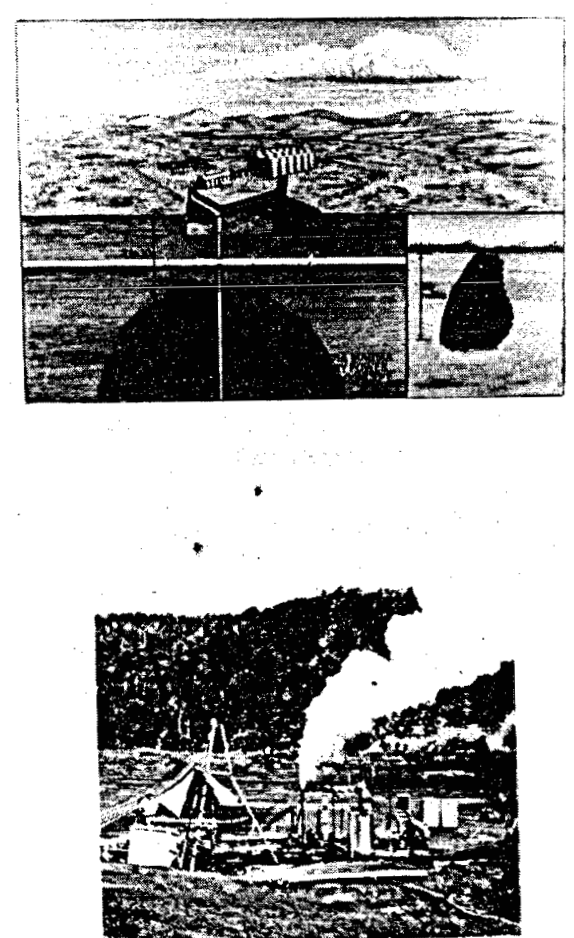
TECHNICAL TRANSFER

NEW COMPANIES ESTABLISHED

PROGRAM

WELL LOGGING INSTRUMENTATION

DRILLING \& COMPLETIONS

ENHANCED OIL RECOVERY

MULTI.FRAC DEVELOPMENT
NEW COMPANY

QUARTEX

THERMODURICS

PRESSURE CORING. INC

PETROLEUM CONCEPTS. INC

ENHANCED ENERGY SYSTEMS

TAILORED PULSE LOADING. INC
NEW ACTIVITY

QUARTZ GAGE \& SENSOR MFR

HIGH TEMPERATURE UPGRADING OF SLICK LINE INSTRUMENTS

CORING SERVICE FOR DEPLETED

RESERVOIRS

DRILL BIT FABRICATION

DOWNHOLE STEAM GENERATORS

FRACTURING SERVICE 


\section{TECHNICAL TRANSFER}

- STAFF MOVEMENTS -

PROGRAM

WEUL LOGGING INSTRUMENTATION

ORILLING TECHNOLOGY

MULT FRAC DEVELOPENT

ENHANCED OIL RECOVER

MATIMA ENERGY
STAFF

EERNISSE

COQUAT

VENERUSO

VARNADO. MCFALL WESENBERG

ST CLAIR

BAKER

POLITO

HUFF

TEVENS

BOADE

STOLLER REFCE SCHMIDT

FOX DONALDSON JOHNSON EISENHOWER MULAC

HIUS
QUARTEX

CRC WIRELINE. INC

GEARHART IND

I PETROLEUM SERVICES

Exxon

PRESSURE CORING. INC

PRITSKER \& ASSOC

PETROLEUM CONCEPTS. INC

OCCIDENTAL PETROLEUM

PHILLIPS PETROLEUM

AILORED PULSE LOADING

ENHANCED ENERGY SYSTEMS

N M STATE U
FOR

QUARTZ CRYSTAL TECHNOLOGY

WELL LOGGING SERVICES

LOGGING TOOL DEVELOPENT

MEASUREMENTS WHILE DRILLING TECHNOLOG

DRILLING - MECHANICAL DESIGN

CORING SERVICES FOR OIL \& GAS

SYSTEMS ANALYSES

DRHLL BIT CUTTER ASSEMBIY

PROCESS RESEARCH \& ROCK MECHANICS

ROCK MECHANICS SHALE

FRACTURE SERVICES

DOWNHOLE STEAM GEMERATOR

GEOPHYSICS INVERSE PROBLEMS 
DISTRIBUTION :

DOE/TIC-4500-UC-13

J. Bresee

Geothermal and Hydropower Technologies Division

Forrestal Building

CE 324

1000 Independence Avenue, SW washington, DC 20585

Don clements

Geothermal and Hydropower

Technologies Division

Forrestal Building

CE 324

1000 Independence Avenue, SW

Washington, DC 20585

David Allen

Geothermal and Hydropower Technologies Division

Forrestal Building

CE 324

1000 Independence Avenue, SW washington, DC 20585

D. Uthus

Office of Deputy Assistant

Secretary for Oil, Gas and

Shale Technology

U. S. Department of Energy

Mail stop D-107

Washington, DC 20545

Joseph J. Tribble

Assistant secretary for Conservation \& Renewable Energy

U. S. Department of Energy

Forrestal Building

1000 Independence Avenue, SW

Washington, DC 20585

Jan W. Mares

Assistant Secretary for Fossil Energy

U. S. Department of Energy

Forrestal Building

1000 Independence Avenue, sW

Washington, DC 20585
James D. Batchelor

Office of Coal Processing

Division of Coal Liquefaction

Department of Energy

Washington, DC 20585

Edward J. Lievens, Jr.

Director, Office of Oil, Gas and shale

U. S. Department of Energy

Washington, DC 20585

Robert M. Hamilton

U. S. Department of Energy

Energy Technology

Germantown

Mail Stop E-338

washington, DC 20545

Senator Jack Schmitt

5313 Dirksen Senate office

Building

Washington, DC 20510

Pat Rogers

c/o Senator Jack Schmitt

5313 Dirksen Senate office Building

Washington, DC 20510

Senator Pete Domenici

4239 Dirksen Senate office

Building

Washington, DC 20510

Paul Gilman

c/o Senator Pete Domenici

4239 Dirksen Senate Office Building

Washington, DC 20510

Congressman Manuel Lujan, Jr. 1323 Longworth House Office Building

washington, DC 20515

Congressman Joe Skeen

1508 Longworth House Office

Building

Washington, DC 20515 
John Rasmussen

c/o Congressman Joe skeen

1508 Longworth House office Building

Washington, DC 20515

Martha Krebs, Staff Director

Subcommittee on Energy

Development and Applications

B374 Rayburn House Office

Building

Washington, DC 20515

Alan B. Claflin

U. S. Department of Energy

Director of Laboratory

Management

Office of Field Operations

ER-42

Washington, DC 20585
400
C. Winter
400
R. P. Stromberg
3160
H. M. Willis
3161
3161
J. E. Mitchell
4000
4200
W. R. Geer
A. Narath
4300
4400
4700
4720
4730
4740
4741
4743
4746
4747
4748
4750
4752
4753
4755
G. Yonas
R. I. Peurifoy, Jr.
A. W. Snyder
E. H. Beckner
D. G. Schueler
W. D. Weart
R. K. Traeger
J. R. Kelsey
H. C. Hardee
B. Granoff
P. J. Hommert
B. E. Bader
V. I. Dugan
H. M. Dodd
D. A. Northrop
(25)
B. W. Marshall
4756 D. Engi
4760 R. W. Lynch
4770
4780
8266
3141
G. E. Brandvold
R. M. Jefferson
E. A. Aas
L. J. Erickson
W. L. Garner
(3) 